American Journal of Clinical Research and Reviews
(ISSN:2576-0505)

\title{
CONSIDERATIONS ON HUMAN IMMUNODEFICIENCY VIRUS (HIV) DISEASE MORTALITY IN BRAZIL BETWEEN 1998 AND 2017
}

\section{Vitor Pereira Contini*; Gabriela Vasconcelos de Moura; Laura de Lima Bigolin; Julia Perito Alfredo}

Universidade Católica de Pelotas

\section{ABSTRACT}

Objective: Analyze mortality rates of the HIV disease in Brazil in a period of 20 years to determinate the behavior of the rates and the pattern of the victims. Methods: Data were collected from the Mortality Information System (SIM) by the Informatics Department of the Unified Health System (DATASUS) regarding deaths from HIV disease. All records and year of death, race, sex, age group, marital status and educational level of the person were considered. Results: In the 20 years studied, 232,274 deaths caused by the disease were recorded, an average of 11,613.7 $( \pm 1092.7)$ per year. White people represent $46.4 \%$, followed by brown, $32.8 \%$. Men are majority throughout the period, with $67.1 \%$ of records. People between 30 and 49 years old have the highest rates, $62.1 \%$ of deaths. Single people were majority, $61.1 \%$ of the total. As for education, people with up to 7 years of education correspond to $44 \%$ of deaths, while people with 12 years and more of education account for only $5.6 \%$. Conclusions: White men, between 30 and 49 years old, single and with up to 7 years of schooling are, according to statistics, the most predisposed to die from the HIV disease. Especially from the data on education, it can be inferred that a higher level of education reduces the risks of death from the disease. Knowing this and the information about single people being more affected, the importance of sex education to early school years is recommended, as well as guidance in primary care.

Keywords: HIV. Infections. Mortality.
${ }^{*}$ Correspondence to Author:

Vitor Pereira Contini

Universidade Católica de Pelotas

How to cite this article:

Vitor Pereira Contini; Gabriela Vasconcelos de Moura; Laura de Lima Bigolin; Julia Perito Alfredo. Patient Medical History \& Medical Record Keeping: Accurate Problem Identification for Effective Solution. American Journal of Clinical Research and Reviews, 2021; 4:19.

\section{eScîPub}

eSciPub LLC, Houston, TX USA. Website: https://escipub.com/ 